\title{
Suits by Foreigners Against Foreign States in United States Courts: A Selective Expansion of Jurisdiction
}

The Foreign Sovereign Immunities Act of $1976^{1}$ codifies the rules governing civil actions against foreign states in United States courts. ${ }^{2}$ The Act clarifies the circumstances under which a federal district court may assert subject-matter and personal jurisdiction in such suits. ${ }^{3}$ The Act also establishes detailed guidelines specifying the circumstances under which a state is barred from raising the defense of foreign sovereign immunity. ${ }^{4}$

One important consequence of the Act is that foreigners ${ }^{5}$ will be able to prosecute more easily claims against foreign states in United States federal courts. ${ }^{6}$ Providing a federal forum for the resolution of disputes between foreigners and foreign states would frequently promote United States interests. It would sometimes be more convenient, however, for the parties and for United States courts to have these disputes resolved in foreign courts. In addition, adjudication of claims against foreign states by United States courts might adversely affect United States foreign relations. This Note argues that the jursdictional provision of the Act allowing suits by

1. 28 U.S.C. $\S \S 1330,1332(\mathrm{a})(2)-(4), 1391(f), 1441(\mathrm{~d}), 1602-1611$ (1976).

2. A foreign state may be sued in either state or federal court. H.R. REP. No. 1487, 94th Cong., 2d Sess. 13, reprinted in [1976] U.S. CODE CONG. \& AD. NEWS 6604, 6611 [hereinafter cited as H.R. REP. No. 1487, with page citations to [1976] U.S. CODE CONG. \& AD. NEWS]. State and federal courts are bound by the same rules of foreign sovereign immunity. 28 U.S.C. $\$ \S 1604-1605,1607$ (1976). But federal courts have jurisdiction whenever a foreign state is denied immunity under the Act. 28 U.S.C. $\S 1330$ (a) (1976). Thus, any suit against a foreign state that could be prosecuted in state court could also be brought in federal court. Dellapena, Suing Foreign Governments and Their Corporations: Sovereign Immunity (pt. 5), 85 CoM. L.J. 497, 497 (1980).

Although much of the following discussion applies to suits brought in either state or federal court, this Note focuses on suits brought in federal court. It is unlikely that many foreigner-foreign state suits will be brought in state courts. Foreign states may remove to federal courts any civil actions commenced against them in state courts. 28 U.S.C. $\$ 1441$ (d) (1976). Also, of the many suits against foreign states since the passage of the Act, only one, Gittler v. German Information Center, 95 Misc. 2d 788, 408 N.Y.S.2d 600 (1978), was brought in state court.

3. 28 U.S.C. $\S 1330(1976)$.

4. 28 U.S.C. $\S \S 1605,1607$ (1976); see p. 1865 infra (describing guidelines).

5. This Note defines a "foreigner" as an individual who is not, at the time the claim arises, a citizen or resident of the United States, or a visitor lawfully admitted to this country. At times, however, a foreign plaintiff may be treated as a United States citizen, or a United States citizen may be treated as a foreign plaintiff. See note 115 infra.

6. Even if the total number of foreigner-foreign state suits in United States courts remains small, these suits will nevertheless be important both because of the amounts of money involved, see, e.g., Verlinden, B.V. v. Central Bank of Nigeria, 488 F. Supp. 1284, 1288 (S.D.N.Y. 1980), affd, No. 807413 (2d Cir. Apr. 16, 1981) (claim for more than $\$ 4.5$ million); Ipitrade Int'l, S.A. v. Federal Republic of Nigeria, 465 F. Supp. 824, 825 (D.D.C. 1978) (enforcing arbitral award of approximately $\$ 9$ million), and because of the foreign policy implications of suits involving foreign states, see p. 1874 infra (discussing foreign policy implications). 
foreigners against foreign states is constitutional, but urges courts to weigh the competing interests implicated by each suit before deciding whether to exercise their jurisdiction. The Note then formulates specific criteria to guide the courts' administration of this interest-balancing test.

\section{The Foreign Sovereign Immunities Act and Foreigner-Foreign State Suits}

The Foreign Sovereign Immunities Act includes a comprehensive set of provisions that specify when foreign states may be sued in United States courts. These provisions increase the chances that a foreigner suing in a United States court can gain jurisdiction over a foreign state, successfully prosecute his or her claim, and recover on a favorable judgment. Because the Act grants foreigners easier access to United States courts, the number of suits filed in this country by foreigners against foreign states may well increase.

\section{A. The Origin of the Foreign Sovereign Immunities Act}

In recent years, foreign states and foreign state agencies have engaged in an increasing number of commercial transactions and other dealings with United States citizens. ${ }^{7}$ In legal disputes arising from these transactions, plaintiffs frequently have been met with the defense of sovereign immunity. ${ }^{8}$ Prior to the passage of the Act, United States courts routinely deferred to the State Department on the question of whether to honor that defense. ${ }^{9}$ The State Department's advice, theoretically governed by legal

7. The legislative history of the Act indicates the variety of such transactions:

Instances of . . . [United States citizen-foreign state] contact occur when U.S. businessmen sell goods to a foreign state trading company, and disputes may arise concerning the purchase price. Another is when an American property owner agrees to sell land to a real estate investor that turns out to be a foreign government entity and conditions in the contract of sale may become a subject of contention. Still another example occurs when a citizen crossing the street may be struck by an automobile owned by a foreign embassy.

H.R. REP. NO. 1487, supra note 2, at 6605.

8. See, e.g., Isbrandtsen Tankers, Inc. v. The President of India, 446 F.2d 1198 (2d Cir.), cert. denied, 404 U.S. 985 (1971) (dismissed because of sovereign immunity); Rich v. Naviera Vacuba, S.A., 295 F.2d 24 (4th Gir. 1961) (same).

9. See, e.g., Ex parte Republic of Peru, 318 U.S. 578 (1943) (dismissal based on State Department recommendation of immunity); Rich v. Naviera Vacuba, S.A., 295 F.2d 24 (4th Cir. 1961) (same); Lowenfeld, Litigating a Sovereign Immunity Claim-The Haiti Case, 49 N.Y.U. L. REV. 377, 389-90 (1974) (discussing judicial deference to State Department immunity recommendations).

When the State Department offered no recommendation, the courts either inferred executive policy from the State Department's silence, see, e.g., Republic of Mex. v. Hoffman, 324 U.S. 30, 38 (1945); Amkor Corp. v. Bank of Korea, 298 F. Supp. 143, 144 (S.D.N.Y. 1969), or applied the "restrictive theory" of sovereign immunity, see note 19 infra (discussing "restrictive theory"), pending clarification of State Department policy, see, e.g., Victory Transp., Inc. v. Comisaria Gen., 336 F.2d 354, 360 (2d Cir. 1964), cert. denied, 381 U.S. 934 (1965) (denying immunity from suit based on foreign state's commercial act); Ocean Transp. Co. v. Ivory Coast, 269 F. Supp. 703, 705-06 (E.D. La. 1967) (same). 
standards, commonly reflected the foreign policy implications of each particular case. ${ }^{10}$ As a consequence, judicial deference to the executive branch was a source of friction in United States relations with other nations, ${ }^{11}$ as well as a threat to the rights of litigants. ${ }^{12}$

A primary purpose of the Foreign Sovereign Immunities Act was to define when a United States court should honor a foreign state's claim of sovereign immunity. ${ }^{13}$ The Act, sponsored by the Departments of State and Justice, includes a set of legal standards to guide the courts in making this determination. ${ }^{14}$ The executive branch no longer has any formal role in these decisions. ${ }^{15}$ Instead, the Act makes clear that when foreign states and foreign state agencies engage in specified activities with significant ties to the United States, they will be subject to suit in United States courts. ${ }^{16}$

One provision apparently permits foreigners to sue foreign states in United States federal courts in many situations in which suit would not formerly have been permitted. ${ }^{17}$ The legislative history of the Act does not reveal Congress' purpose in expanding federal jurisdiction in this fashion. Nevertheless, courts agree that the Act purports to confer jurisdiction on the federal courts over foreigner-foreign state suits. ${ }^{18}$

10. See Maier, The Proposed Sovereign Immunities Act: Its Effect on Judicial Deference, 70 AM. SOC'Y INT'L L. PROC. 48, 50 (1976) (executive immunity determinations influenced by amount of political pressure generated by foreign state); cf. note 19 infra (describing inconsistencies in State Department immunity recommendations).

11. See H.R. REP. No. 1487, supra note 2, at 6606 (State Department role in immunity determinations may have "adverse consequences" when Department is unwilling to support foreign sovereign's claim to immunity); Lowenfeld, Claims Against Foreign States-A Proposal for Reform of United States Law, 44 N.Y.U. L. REV. 901, 913 (1969) (State Department role in immunity determinations likely to have been an "irritant" to United States foreign relations).

12. See Moore, The Role of the State Department in Judicial Proceedings, 31 FordHaM L. REV. 277, 299-300 (1962) (lack of procedural safeguards in State Department immunity determinations infringed on rights of private litigants); Comment, Proposed Draft Legislation on the Sovereign Immunity of Foreign Governments: An Attempt to Revest the Courts with a Judicial Function, 69 NW. U.L. REV. 302, 324 (1974) (same).

13. See H.R. REP. No. 1487, supra note 2, at 6605 (setting forth Act's purposes).

14. 28 U.S.C. $\$ \S 1605,1607$ (1976).

15. See H.R. REP. No. 1487, supra note 2, at 6606 (sovereign immunity decisions to be made by courts rather than by executive). But cf. Letter from Monroe Leigh, Legal Adviser of the State Department, to Edward H. Levi, United States Attorney General (Nov. 10, 1976), reprinted in 41 Fed. Reg. 50,883, 50,884 (1976) (State Department will submit amicus opinions in cases of significant interest to federal government).

16. See pp. 1865-67 infra (describing power of federal courts to adjudicate claims against foreign states). The Act's definition of a "foreign state" includes a political subdivision of a foreign state. It also includes an entity that is neither a citizen of a state of the United States nor a creation of the laws of any third country, and that "is an organ of a foreign state or political subdivision thereof, or a majority of whose shares or other ownership interest is owned by a foreign state or political subdivision thereof." 28 U.S.C. $\$ 1603$ (1976).

17. See TAN 35-36 infra (discussing 28 U.S.C. § 1330 (1976)).

18. See, e.g., Verlinden, B.V. v. Central Bank of Nigeria, No. 80-7413, slip op. at 2560-62 (2d Cir. Apr. 16, 1981) (dictum) (section 1330 allows suits by foreigners against foreign states); Ipitrade Int'l, S.A. v. Nigeria, 465 F. Supp. 824 (D.D.C. 1978) (enforcing arbitral award in favor of foreigner against foreign state). But see Santos Miranda v. Transportes Aereos Portugueses, No. 78-2143 (N.D. Ill. Nov. 22, 1978) (only United States citizens may sue under section 1330). 


\section{B. The Act as Applied to Foreign Plaintiffs}

A foreigner who sues a foreign state in a United States federal court must overcome several potential obstacles to successful prosecution of his or her suit. The suit may be barred by the doctrine of sovereign immunity. ${ }^{19}$ In addition, an explicit grant of subject-matter jurisdiction must exist for a federal court to hear the suit. ${ }^{20}$ This jurisdictional grant must be within the scope of the federal judicial power as defined by Article III of the Constitution. ${ }^{21}$ The court also must have territorial jurisdiction over the dispute, ${ }^{22}$ and this territorial jurisdiction must not violate due process. ${ }^{23}$ Finally, satisfaction of a validly obtained judgment may be impossible if the foreign state's property is immune from execution.

19. The Supreme Court first recognized the doctrine of sovereign immunity in The Schooner Exchange v. McFaddon, 11 U.S. (7 Cranch) 116 (1812). In 1943, the Supreme Court announced that suits against foreign states would be dismissed whenever the State Department so recommended. Ex parte Republic of Peru, 318 U.S. 578, 588 (1943). The State Department formally adopted the "restrictive theory" of immunity in 1952 in the famous "Tate Letter," which purported to establish Department policy on the making or withholding of immunity recommendations. Letter from Jack B. Tate, Acting Legal Adviser of the State Department, to Philip B. Perlman, Acting Attorney General (May 19, 1952), reprinted in 26 DEP'T STATE BULL. 984, 984-95 (1952).

Under this theory, states may claim sovereign immunity for acts that can be performed only by a state, but not for acts that can be performed by a private person as well as by a state. Kahale \& Vega, Immunity and Jurisdiction: Toward a Uniform Body of Law in Actions Against Foreign States, 18 COLUM. J. TRANSNAT'L L. 211, 212 (1979).

Despite formal acceptance of the Tate Letter, however, the State Department's recommendations to the courts on whether to grant or withhold immunity were frequently inconsistent with Tate Letter principles. See, e.g., Rich v. Naviera Vacuba, S.A., 295 F.2d 24, 26 (4th Cir. 1961) (accepting State Department suggestion to grant foreign state immunity from suit based on that state's commercial activity); Chemical Natural Resources, Inc. v. Republic of Venez., 420 Pa. 134, 160-61, 215 A.2d 864, 876-77, cert. denied, 385 U.S. 822 (1966) (same).

20. Kline v. Burke Constr. Co., 260 U.S. 226, 234 (1922) (every court but Supreme Court "derives its jurisdiction wholly from the authority of Congress"); Sheldon v. Sill, 49 U.S. (8 How.) 441, 449 (1850) (federal courts "created by statute can have no jurisdiction but such as the statute confers").

21. See National Mut. Ins. Co. v. Tidewater Transfer Co., 337 U.S. 582, 615, 645, 655 (1949) (concurring and dissenting opinions) (federal court may not take jurisdiction over case not within federal judicial power as defined by Article III); Hodgson v. Bowerbank, 9 U.S. (5 Cranch) 303, 304 (1809) (same). This general rule is subject to limited exceptions. See generally 13 C. WRIGHT, A. MILLER, \& E. COOPER, FEDERAL PRACTICE AND PROCEDURE § 3521 (1975) (discussing removal and pendent jurisdiction, and controversial idea that Congress has power under Article I to confer jurisdiction on federal courts).

22. Territorial jurisdiction may be based, for example, on a "long-arm" statute. The term "longarm" refers to a type of jurisdictional statute that bases personal jurisdiction over a defendant on acts performed or causing consequences in the forum. See R. WEINTRAUB, COMMENTARY ON THE CONFLICT OF LAWS 148-178 (2d ed. 1980) (discussing "long-arm" statutes generally).

23. See Thomas P. Gonzalez Corp. v. Consejo Nacional, 614 F.2d 1247, 1254-55 (9th Cir. 1980) (because unrelated to claim, defendant's activities within state did not establish minimum contacts necessary for jurisdiction); Carey v. National Oil Corp., 592 F.2d 673, 676 (2d Cir. 1979) (due process requires that defendant foreign state have certain "minimum contacts" with forum state); $c f$. World-Wide Volkswagen Corp. v. Woodson, 444 U.S. 286, 295-99 (1980) (defendant's sale of automobile in New York to New York residents involved in accident in Oklahoma insufficient contact for Oklahoma to assert jurisdiction); Shaffer v. Heitner, 433 U.S. 186, 213-17 (1977) (assertion of jurisdiction by Delaware court based on defendants' holdings in Delaware corporation that were unrelated to cause of action violated defendants' due process rights). 
Under the Foreign Sovereign Immunities Act, a foreigner can overcome all of these obstacles. The Act provides detailed standards for courts to use in determining the validity of a sovereign immunity defense. ${ }^{24}$ Those standards contain two facets, relating to the nature of the challenged activity and the contacts with the United States arising from that activity. For example, the Act withholds immunity from claims based on commercial activities of a foreign state that are conducted in the United States or that cause direct effects in the United States. ${ }^{25}$ If a foreign state expropriates property in violation of international $\mathrm{law}^{26}$ and transfers that property to a state agency engaged in a commercial activity in the United States, the agency is not protected by sovereign immunity. ${ }^{27}$ Suit is also permitted to seek recompense for certain noncommercial torts causing injury in the United States, ${ }^{28}$ and to determine ownership of immovable property in the United States or of property in the United States acquired by gift or bequest. ${ }^{29}$ In addition, a foreign state may be sued in a United States court if it has waived its immunity from suit. ${ }^{30}$ Counterclaims ${ }^{31}$ and commercial claims in admiralty ${ }^{32}$ are also permitted.

The Act's provisions defining the types of foreign state activity and the contacts with United States territory that justify abrogating sovereign immunity also define the scope of federal subject-matter jurisdiction. Formerly, the federal courts had subject-matter jurisdiction in foreigner-for-

24. 28 U.S.C. $\S \S 1604-1605,1607$ (1976).

25. 28 U.S.C. $\S 1605(a)(2)$ (1976). The commercial act exception is probably the most important exception to sovereign immunity created by the Act. See Dellapena, Suing Foreign Governments and Their Corporations: Sovereign Immunity (pt. 2), 85 CoM. L.J. 228, 230 (1980) (describing commercial act exception as "core" of Act). It is not entirely clear, however, what distinguishes a commercial act from other types of acts. $I d$. at 232-33 (discussing definition of commercial act). Nevertheless, some broad outlines may be drawn. An act is commercial or non-commercial depending on its "nature" rather than its "purpose." 28 U.S.C. $\S 1603$ (e) (1976). Examples of commercial activities provided in the Act's legislative history include military procurement, government airlines, and embassy repair contracts. H.R. REP. No. 1487, supra note 2, at 6614-15.

26. A taking will probably be held to violate international law if compensation is not "prompt, adequate and effective," a standard established for United States courts by the Hickenlooper Amendment to the Foreign Assistance Act of 1964, 22 U.S.C. $\S 2370(c)(2)(1976)$, and specifically approved in the legislative history of the Act, see H.R. REP. NO. 1487, supra note 2, at 6618 .

27. 28 U.S.C. \& 1605(a)(3) (1976). The expropriation exception applies, in part, to property owned or operated by a foreign state "agency or instrumentality" engaged in a commercial activity in the United States. 28 U.S.C. $\$ 1605$ (a)(3) (1976). Because the property need not be present in the United States, this exception to immunity is potentially quite broad. See Dellapena, supra note 25, at 234 (discussing territorial contacts required by expropriation exception and potential breadth of jurisdiction under this provision).

28. 28 U.S.C. $\S 1605(\mathrm{a})(5)(1976)$.

29. 28 U.S.C. $\$ 1605(\mathrm{a})(4)(1976)$.

30. 28 U.S.C. § 1605(a)(1) (1976). Waiver may be either explicit, as by contract or treaty, or implicit, as by submission to arbitration. See Clarke, The Foreign Sovereign Immunities Act of 1976, 3 N.C. J. INT'L L. \& COM. REG. 206, 218-19 (1978) (discussing waiver of immunity).

31. 28 U.S.C. $\$ 1607$ (1976).

32. 28 U.S.C. $\S 1605$ (b) (1976). 
eign state suits only when the claims arose in admiralty ${ }^{33}$ or under federal law. ${ }^{34}$ Now the Act grants the federal district courts subject-matter jurisdiction over any civil action against a foreign state in which the foreign state is not immune from suit. ${ }^{35}$ This jurisdictional provision includes no limitation based on the nationality of the plaintiff. Because the Act's legislative history fails to reveal the purposes of this provision, the courts generally have accepted the literal interpretation that it creates federal jurisdiction in foreigner-foreign state suits. ${ }^{36}$

The Act authorizes a federal district court to assert personal jurisdiction over a foreign state if there has been a valid service of process ${ }^{37}$ and if the court has subject-matter jurisdiction over the case. ${ }^{38}$ Since a federal court has subject-matter jurisdiction whenever the foreign state is barred from raising the defense of sovereign immunity, ${ }^{39}$ the reach of personal jurisdiction is likewise determined by the Act's criteria for deciding the validity of claims of sovereign immunity. Given the nature of these criteria,${ }^{40}$ jurisdiction conferred by the Act is roughly coextensive with the limitations imposed by the due process clause. ${ }^{41}$

The constitutionality of the Act's grant of subject-matter jurisdiction is currently in doubt. Article III does not expressly extend the federal judicial power to suits between foreigners and foreign states. Thus the constitutionality of such jurisdiction may be upheld, if at all, only under the

33. 28 U.S.C. § 1333 (1976); cf. Canada Malting Co. v. Paterson S.S., Ltd., 285 U.S. 413, 42022 (1932) (dictum) (federal district court has discretionary jurisdiction over suits between forcigners in admiralty); Odita v. Elder Dempster Lines, Ltd., 286 F. Supp. 547, 549, 551 (S.D.N.Y. 1968) (upholding admiralty jurisdiction in suit between foreigners).

34. 28 U.S.C. $\$ 1331$ (a) (1976); cf. Lauritzen v. Larsen, 345 U.S. 571, 574-75 (1953) (by implication) (federal district court has jurisdiction over suit under federal statute by foreign seaman against foreign employer); Doidge v. Cunard S.S. Co., 19 F.2d 500, 502 (1st Cir. 1927) (dictum) (one alien may not sue another in federal court unless federal question is raised).

35. 28 U.S.C. $\$ 1330$ (a) (1976).

36. See p. 1863 supra.

37. See 28 U.S.C. $\$ 1608$ (1976) (setting forth requirements for valid service of process on foreign states in both state and federal courts).

38. 28 U.S.C. $\$ 1330$ (b) (1976). The Act abolished attachment jurisdiction as a basis for jurisdiction over foreign states. 28 U.S.C. $\$ \S 1609,1610(d)(1976)$; see Del Bianco, Execution and Attachment Under the Foreign Sovereign Immunities Act of 1976, 5 YALE STUD. WORLD PUB. ORD. 109, 143-44 (1978) (discussing prohibition of jurisdictional attachment). But see New Eng. Merchants Nat'l Bank v. Iran Power, 495 F. Supp. 73 (S.D.N.Y. 1980) (asserting attachment jurisdiction following failure of all attempts to serve process on Iranian government-owned company).

39. 28 U.S.C. $\$ 1330$ (a) (1976).

40. Each exception to immunity contains a requirement of territorial contacts designed by the drafters to meet judicially-developed due process requirements. H.R. REP. NO. 1487, supra note 2 , at 6612 .

41. In general, courts have interpreted the Act's grant of personal jurisdiction to be coextensive with the limitations on jurisdiction imposed by due process. See East Europe Domestic Int'l Sales Corp. v. Terra, 467 F. Supp. 383, 387 (S.D.N.Y. 1979) (construing commercial act exception to sovereign immunity as requiring "minimum contacts"). Whether the territorial contacts required by the Act may be more restrictive than those required by due process is not clear. See Kahale \& Vega, supra note 19, at 246 n.161 (legislative history of Act does not clearly indicate whether commercial act exception was intended to extend as far as "minimum contacts" rule permits). 
Article III grant of federal judicial power to "all Cases, in Law and Equity, arising under this Constitution, the Laws of the United States, and Treaties made, or which shall be made, under their Authority " 42 The Second Circuit Court of Appeals in Verlinden, B.V. v. Central Bank of Nigeria ${ }^{43}$ held that the Act's grant of federal subject-matter jurisdiction did not fall within this "federal question" jurisdiction under Article III. ${ }^{4}$ The court's analysis, however, is open to dispute.

The Verlinden court failed to note the essential similarity between foreigner-foreign state jurisdiction and the type of jurisdiction approved in Osborn v. Bank of the United States, ${ }^{45}$ the seminal Article III federal question case. In Osborn, the Supreme Court upheld federal jurisdiction of a suit based on state law, but brought in federal court, under a statute granting the federally-chartered bank authority "to sue and be sued . . . in every Circuit Court of the United States."46 According to the Court,

when a question to which the judicial power of the Union is extended by the constitution, forms an ingredient of the original cause, it is in the power of Congress to give the Circuit Courts jurisdiction of that cause, although other questions of fact or of law may be involved in it. ${ }^{47}$

42. U.S. CONST. art. III, § 2.

43. No. 80-7413, slip op. at 2565-75 (2d Cir. Apr. 16, 1981).

44. The scope of federal question jurisdiction under Article III has not frequently been interpreted. But a federal statutory provision, 28 U.S.C. $\$ 1331$ (1976), using essentially the same language as the Article III federal question clause, has frequently been the subject of litigation. Section 1331 has been construed to include limitations, notably under the "well-pleaded complaint" rule, that do not necessarily constrain Article III federal question jurisdiction. The well-pleaded complaint rule holds that federal jurisdiction will be upheld only when the federal question relied upon to bring the suit within section 1331 is an essential part of plaintiff's complaint. See Smith v. Kansas City Title \& Trust Co., 255 U.S. 180, 201-02 (1921) (federal jurisdiction under federal question statute upheld because plaintiff's complaint disclosed need to interpret federal law); Ivy Broadcasting Co. v. AT\&T, 391 F.2d 486, 492 (2d Cir. 1968) (same). Because the issue of sovereign immunity is an affirmative defense to be raised by the defendant, see H.R. REP. No. 1487 , supra note 2 , at 6616 , it is not a federal question that would suffice under the well-pleaded complaint rule. Yet statutory grants of jurisdiction have been held constitutional when based on Congressional authority to regulate a substantive area of law even though cases brought under these statutes would not have satisfied the wellpleaded complaint rule. Sec, e.g., Williams v. Austrian, 331 U.S. 642, 657-58 (1947) (by implication) (trustee in bankruptcy may pursue in federal court a private cause of action arising under and wholly governed by state law); Schumacher v. Beeler, 293 U.S. 367, 374 (1934) (by implication) (same). Thus, as the Second Circuit recognized in Verlinden, B.V. v. Central Bank of Nigeria, No. 80-7413, slip op. at 2570 (2d Cir. Apr. 16, 1981), Article III federal question jurisdiction is probably broader than section 1331 federal question jurisdiction. But because cases interpreting the Article III federal question clause have been so few, the precise scope of that clause is uncertain.

The Verlinden court held that the foreigner-foreign state jurisdiction conferred by section 1330 neither satisfied the well-pleaded complaint rule nor fell within the scope of the Article III jurisdiction that arguably extends beyond jurisdiction within the well-pleaded complaint rule. Id. at 2565-75.

45. 22 U.S. (9 Wheat.) 738 (1824). Although the rule in Osborn referred to here is actually dictum, it was made a holding in the companion case, Bank of the United States v. Planters' Bank of Georgia, 22 U.S. (9 Wheat.) 904 (1824).

46. 22 U.S. ( 9 Wheat.) 738,817 (1824).

47. Id. at 823 . 
In this case, the act of incorporation by the federal government sufficed to make the suit by the Bank of the United States a federal question suit. ${ }^{48}$

Suits against foreign states also should be considered to raise a federal question that, like the incorporation of the Bank in Osborn, forms an "ingredient of the original cause." ${ }^{39}$ Under traditional doctrine, foreign states were immune from suit as a matter of federal law. ${ }^{50}$ The partial abrogation of this immunity has taken the form of exceptions based on federal standards. ${ }^{51}$ An essential question, therefore, in every suit against a foreign state is whether federal sovereign immunity standards permit the suit. This implicit federal question is made explicit by section 1330;52 accordingly, that section should be considered within the federal question jurisdiction of Article III.

Should the issue of constitutionality be resolved in favor of the foreign plaintiff, the Act makes it more likely that claimants can recover on judgments against foreign states. Prior to the Act, the property of a foreign state was absolutely immune from execution to satisfy a judgment. ${ }^{53}$ The Act abrogates this absolute immunity by allowing enforcement of judgments against foreign state property located in the United States. ${ }^{54}$

\section{G. Encouragement of Foreigner-Foreign State Suits}

Expanded access to United States courts, as well as other factors, will encourage foreigners to sue foreign states in United States courts more frequently in the future. ${ }^{55}$ One obvious consideration that might lead a foreigner to select a United States forum is that the action might be barred in other nations' courts by the doctrine of sovereign immunity. ${ }^{56}$ Even if

48. The power of the Bank to acquire rights, to transact business, to make and sue upon contracts, "is given and measured by its charter, and that charter is a law of the United States." Id. at 823.

49. See 1 J. MOORE, Federal PRACTICE T 0.66 [4] n.11 (2d ed. 1980) (Osborn supports federal jurisdiction over foreigner-foreign state suits).

50. See Berizzi Bros. Co. v. S.S. Pesaro, 271 U.S. 562 (1926); The Schooner Exchange v. McFaddon, 11 U.S. (7 Cranch) 116 (1812).

51. See note 19 supra.

52. See J. MOORE, supra note 49 , at II $0.66[4]$ n.11 ( $\$ 1330$ blends substance and procedure by incorporating immunity standards).

53. See T. GIUTTARI, THE AMERICAN LAW OF SOVEREIGN IMMUNITY 254-309 (1970) (discussing pre-Act immunity of foreign state property from execution).

54. 28 U.S.C. $\S \S 1609-1611$ (1976). See Del Bianco, supra note 38, at 109, 113-143 (discussing limitations on immunity of foreign state property from execution under Act).

55. Cf. Comment, The State Immunity Act 1978, 42 MOD. L. REV. 72, $72-73$ (1979) (British State Immunity Act of 1978 was passed partly. out of fear that Foreign Sovereign Immunities Act would make New York more attractive location than London for the transaction of business involving foreign states).

56. Many suits against foreign states that can now be prosecuted in United States courts as a result of the Act would be barred in foreign courts by sovereign immunity. Compare N. LEECH, C. OLIVER, \& J. SWEENEY, THE INTERNATIONAL LEGAL SYSTEM 308 (1973) ("socialist" countries maintain that sovereign states are absolutely immune from jurisdiction of other states' courts) with p. 1865 
the plaintiff's claim is not barred, the plaintiff may fear that the defendant state's own courts will be biased in favor of the defendant. ${ }^{57} \mathrm{~A}$ foreigner might also select a United States forum in order to take advantage of a favorable substantive law rule. This could happen, for example, when United States law applies under United States choice of law rules but not under the choice of law rules of the alternative forum, ${ }^{58}$ and where United States law is more favorable to the plaintiff than foreign law. ${ }^{59} \mathrm{~A}$ foreigner might also want to take advantage of United States procedural rules such as the liberal federal discovery rules. ${ }^{60}$

The Act makes United States courts more attractive to foreigners because it makes the outcome of suits against foreign states more predictable. Most importantly, codification of the rules of sovereign immunity removes the uncertainty formerly associated with State Department immunity recommendations. ${ }^{61}$ As case law interpreting the statutory standards develops, this predictability will be further enhanced.

In addition, the provisions of the Act relating to waiver of immunity may encourage the designation of United States courts in choice-of-forum clauses in contracts between foreigners and foreign states. These provisions uphold waivers of immunity from suit, ${ }^{62}$ attachment, ${ }^{63}$ and execution, ${ }^{64}$ and forbid withdrawal of a waiver absolute on its face, ${ }^{65}$ making it easier for a plaintiff to circumvent a sovereign immunity defense.

supra (discussing immunity provisions of Foreign Sovereign Immunities Act).

57. See note 94 infra (discussing difficulty of pressing claims abroad where forum state is a party); cf. Carl Zeiss Stiftung v. V.E.B. Carl Zeiss, Jena, 293 F. Supp. 892, 906-07 (S.D.N.Y. 1968), modified, 433 F.2d 686 (2d Cir. 1970), cert. denied, 403 U.S. 905 (1971) (denying effect to judgment of East German court in controversy between East and West German firms because of general bias of East German courts).

58. Given the universal tendency of courts to prefer forum law over foreign law, see R. LEFLAR, AMERICAN CONFLICTS LAW 6 (1977), such conflicts of law are bound to arise.

59. See Flynn, The Application of Forum Non Conveniens in Maritime Personal Injury Actions Brought by Foreign Seamen in Federal Courts, 1 HASTINGS INT'L \& COMP. L. REv. 77,77 n.1 (1977) (foreign seamen frequently sue employers for personal injuries in United States courts, where liberal provisions of Jones Act are applied, rather than in foreign courts, where foreign law affords comparatively meager compensation).

60. See R. SCHLESINGER, COMPARATIVE LAW 399-400 (4th ed. 1980) (plaintiffs engaged in litigation in civil law country sometimes institute a second action in United States merely to take advantage of United States discovery rules).

61. See H.R. REP. NO. 1487, supra note 2, at 6605 (lack of "firm standards as to when a foreign state may validly assert the defense of sovereign immunity" will be alleviated by Act); von Mehren, The Foreign Sovereign Immunities Act of 1976, 17 COLUM. J. TRANSNAT'L L. 33, 66 (1978) (Act will lead to increased predictability in immunity decisions).

62. 28 U.S.C. $\S 1605(a)(1)(1976)$.

63. 28 U.S.C. $\S 1610$ (d) (1976).

64. 28 U.S.C. $\S 1610(a)(1)(1976)$.

65. 28 U.S.C. $\$ \S 1605(a)(1), 1610(a)(1)$, (d) (1976). Prior to the passage of the Act, foreign states were sometimes allowed to rescind contractual waivers. Sec, e.g., Isbrandtsen Tankers, Inc. v. The President of India, 446 F.2d 1198 (2d Cir.), cert. denied, 404 U.S. 985 (1971); H.R. REP. No. 1487, supra note 2, at 6617 (discussing practice of allowing withdrawal of waivers). 


\section{Desirability of Resolution of Foreigner-Foreign State Suits in United States Courtsp}

In many cases, the resolution of disputes between foreigners and foreign states by United States courts will serve United States policy interests. The courts of another nation, however, will sometimes offer a more convenient forum for the resolution of these disputes. In addition, important United States foreign policy interests may be adversely affected if a foreign state objects to a United States court's assertion of jurisdiction.

\section{A. United States Interests in Foreigner-Foreign State Suits}

The United States may have an interest in applying United States laws to foreigner-foreign state disputes. Some United States laws, for example, are designed to deter undesirable behavior affecting the United States ${ }^{66}$ to ensure the payment of debts incurred in the United States, ${ }^{67}$ and to remove clouds on titles to property located in this country. ${ }^{68}$ In some cases these policies will be adequately served only by the enforcement of United States law, even if all parties to the suit are foreigners. ${ }^{69}$

Even when United States law does not apply, permitting foreigner-foreign state suits in United States courts may help promote United States human rights policies. Such suits may aid diplomatic, ${ }^{70}$ judicial, ${ }^{71}$

66. Cf. Conklin v. Horner, 38 Wis. 2d 468, 477, 157 N.W.2d 579, 583 (1968) (Wisconsin interest in promoting highway safety may be served by allowing nonresident to sue for damages under Wisconsin law); Currie, The Growth of the Long Arm: Eight Years of Extended Jurisdiction in Illinois, 1963 U. ILL. L.F. 533, 543-44 (1963) (state may have interest in allowing suit between nonresidents under forum law to deter undesirable behavior).

67. Cf. Carroll v. Lanza, 349 U.S. 408, 413 (1955) (personal injury suit between foreign parties may be adjudicated in forum where injury occurred in order to ensure payment of local creditors); Gkiafis v. Steamship Yiosonas, 342 F.2d 546, 557 (4th Cir. 1965) (same).

68. Cf. R. WEINTRAUB, supra note 22, at 400 (choice of law rule favoring law of situs of real property in dispute over title is useful in maintaining orderly record of real estate titles).

69. In addition, applying United States law to a foreign state doing business in the United States would ensure that foreign enterprises do not enjoy an unfair competitive advantage over American enterprises. Cf. Hellenic Lines Ltd. v. Rhoditis, 398 U.S. 306, 310 (1970) (failure to apply Jones Act in suit by foreign seaman against foreign defendant would give foreigner doing extensive business in United States competitive advantage over United States citizens); Strathearn S.S. Co. v. Dillon, 252 U.S. 348, 354-55 (1920) (United States statute allowing seamen in port to demand half of accrued wages should apply to foreign seamen to avoid discrimination against United States citizens in hiring).

70. The United States has signed and ratified various treaties intended to promote human rights. See, e.g., U.N. CHARTER art. 1, para. 3 (one purpose of United Nations is "[t]o achieve international co-operation . . . in promoting and encouraging respect for human rights and for fundamental freedoms for all"); Geneva Convention Relative to the Protection of Civilian Persons in Time of War, opened for signature Aug. 12, 1949, art. 3, para. 1, 6 U.S.T. 3516, T.I.A.S. No. 3365 (entered into force with respect to the United States Feb. 2, 1956) (listing prohibited atrocities and declaring that "[p]ersons taking no active part in the hostilities ... shall in all circumstances be treated humanely").

71. See, e.g., Filartiga v. Pena-Irala, 630 F.2d 876 (2d Cir. 1980) (construing Alien Tort Claims Act and international law to allow foreigner to sue former head of Peruvian secret police, in United States federal court, for torture inflicted in Peru); Letelier v. Chile, 488 F. Supp. 665 (D.D.C. 1980) (denying immunity to Chile in suit based on politically motivated bombing by Chilean agents). 
and statutory ${ }^{72}$ efforts to protect individuals against repressive measures by other states when the applicable foreign or international law comports with our ideas of fairness.

The foreigner-foreign state suits that may be heard in United States courts must have sufficient contacts with the United States to support jurisdiction under the Act. ${ }^{73}$ Such suits are therefore particularly likely to implicate United States policy concerns. Under the noncommercial tort exception, for example, courts have jurisdiction over suits based on death, personal injury, or damage to property that occurs in the United States. ${ }^{74}$ Swift and accurate adjudication of disputes arising from such events is plainly of concern to the United States. ${ }^{75}$ Nevertheless, adjudication in United States courts of some foreigner-foreign state suits permitted by the Act would not serve the interests of the United States or of the parties involved.

\section{B. The Possible Inconveniences of a United States Forum}

In some foreigner-foreign state suits permitted by the Act, it may not be convenient for the parties to litigate the case in a United States court. Moreover, some other forum may be able to assert jurisdiction over the defendant, award complete relief on related claims, and enforce any favorable judgment. The foreign forum will be more convenient, for example, if compulsory process over witnesses ${ }^{76}$ and documents ${ }^{77}$ can be obtained there, or if the cost of transporting ${ }^{78}$ and presenting ${ }^{79}$ evidence is

72. See, e.g., Foreign Assistance Act of 1974, 22 U.S.C. § 2304(a)(2) (Supp. III 1979) ("Except under circumstances specified in this section, no security assistance may be provided to any country the government of which engages in a consistent pattern of gross violations of internationally recognized human rights."); Special Central American Assistance Act of 1979, 22 U.S.C.A. § 2346b(d) (West 1980 Special Pamphlet) (directing President to terminate monetary assistance to Nicaragua if the government of that country "engages in a consistent pattern of gross violations of internationally recognized human rights").

73. See p. 1865 supra.

74. 28 U.S.C. § 1605(a)(5) (1976).

75. See Reese, Choice of Law in Torts and Contracts and Directions for the Future, 16 CoLUM. J. TRANSNAT'L L. 1, 3 (1977) (state where injury to person or to tangible property occurred inevitably will have policy interest in tort).

76. See Papageorgiou v. Lloyds of London, 436 F. Supp. 701, 703 (E.D. Pa. 1977) (dismissing suit in favor of foreign forum in part because witnesses available there were beyond subpoena power of United States court); Rini v. New York Cent. R.R., 429 Pa. 235, 240, 240 A.2d 372, 374 (1968) (same).

77. See Schertenleib v. Traum, 589 F.2d 1156, 1165 (2d Cir. 1978) (dismissing suit in part because documents were beyond court's subpoena power but not beyond that of alternative forum); Paper Operations Consultants Int'l, Ltd. v. S.S. Hong Kong Amber, 513 F.2d 667, 672 (9th Cir. 1975) (same).

78. See Fitzgerald v. Westland Marine Corp., 369 F.2d 499, 501 (2d Cir. 1966) (dismissing suit in part because of cost of bringing witnesses from alternative jurisdiction); Dorizos v. Lemos and Pateras, Ltd., 437 F. Supp. 120, 123 (S.D. Ala. 1977) (same).

79. See Schertenleib v. Traum, 589 F.2d 1156, 1165 (2d Cir. 1978) (dismissing suit on ground that substantial expense of translating evidence could be avoided if suit were tried in Switzerland); $c$. 
less in that forum. When a view of the premises is desirable, litigating the case in the local forum will obviously be more convenient for both the plaintiff and the defendant. ${ }^{80}$ Also, if foreign law governs the suit, litigating the case in the forum of the applicable law will be more convenient for the parties and less likely to lead to error. ${ }^{81}$

In addition, a suit within United States court jurisdiction under the Act might be brought more appropriately in another forum if that forum has a greater interest in the suit. A state has a particular interest, for example, in having local controversies decided in its own courts. ${ }^{82}$ Similarly, a foreign jurisdiction may have a superior interest in a dispute if the plaintiff is a resident of that forum. ${ }^{83}$ If no United States interest is implicated, the burden on United States courts of trying such a suit may make more appropriate dismissal of the suit in favor of the alternative jurisdiction. ${ }^{84}$

Although United States courts profess a general obligation to hear cases within their jurisdiction, ${ }^{85}$ this rule is riddled with exception ${ }^{86}$ and should

Constructora Ordaz, N.V. v. Orinoco Mining Co., 262 F. Supp. 90, 92 (D. Del. 1966) (denying motion to dismiss on forum non conveniens grounds in part because trial in Venezuela would require translating documents and testimony into Spanish).

80. See Gulf Oil Corp. v. Gilbert, 330 U.S. 501, 508 (1947) (dictum) (location of premises is one factor for court to consider in deciding forum non conveniens motion); Abouchalache v. Hilton Int'l Co., 464 F. Supp. 94, 98 (S.D.N.Y. 1978), aff'd mem. sub nom. Collins v. Hilton Int'l Co., 628 F.2d 1344 (2d Cir. 1980) (dismissing suit on forum non conveniens grounds in part because premises were in England).

81. See Michell v. General Motors Corp., 439 F. Supp. 24, 27-28 (N.D. Ohio 1977) (suit governed by Ontario law dismissed on forum non conveniens grounds in part because court felt "this case should be tried in Ontario before a court which has a much better grasp of its own law than a court in the United States could hope to have"); Del Rio v. Ballenger Corp., 391 F. Supp. 1002, 1004 (D.S.C. 1975) (forum non conveniens dismissal appropriate in part because courts of Panama more competent to apply their own law).

82. See Ionescu v. E.F. Hutton \& Co. (France) S.A., 465 F. Supp. 139, 147-48 (S.D.N.Y. 1979) (dismissing suit in part because relevant events occurred in France, giving that country a greater interest in adjudicating the claim); cf. Gulf Oil Corp. v. Gilbert, 330 U.S. 501, 509 (1947) (dictum) (among factors weighing against dismissal on forum non conveniens ground is "local interest in having localized controversies decided at home").

83. See MacLeod v. MacLeod, 383 A.2d 39, $43-44$ (Me. 1978) (dismissing suit in part because Virginia, the alternative forum, had greater interest in enforcing right of Virginia resident to alimony and support payments); cf. Archibald v. Cinerama Hotels, 15 Cal. 3d 853, 859, 126 Cal. Rptr. 811, 815, 544 P.2d 947, 951 (1976) (in bank) (refusal of California courts to dismiss suits by California residents on forum non conveniens grounds except in extreme cases "reflects an overriding state policy of assuring California residents an adequate forum for the redress of grievances").

84. See Papageorgiou v. Lloyds of London, 436 F. Supp. 701, 703 (E.D. Pa. 1977) (dismissing suit in part because "[j]urors, courts and the community in general in the Eastern District of Pennsylvania should not be burdened with litigation that has only the most remote connection with the District"); Varkonyi v. S.A. Empresa de Viacao Airea Rio Grandense, 27 A.D.2d 731, 731, 277 N.Y.S.2d 577, 579 (1967) (cost considerations favor forum non conveniens dismissal in cases with few local contacts); Comment, Forum Non Conveniens, Injunctions Against Suit and Full Faith and Credit, 29 U. CHI. L. REV. 740, 749 (1962) (crowding of local dockets weighs in favor of forum non conveniens dismissal in primarily foreign controversies).

85. See Colorado River Water Conserv. Dist. v. United States, 424 U.S. 800, 817 (1976) (federal courts have a "virtually unflagging obligation . . . to exercise the jurisdiction given them"); Cohens v. Virginia, 19 U.S. (6 Wheat.) 264, 404 (1821) (Marshall, C.J.) ("We have no more right to decline the exercise of jurisdiction which is given, than to usurp that which is not given.")

86. See, e.g., Younger v. Harris, 401 U.S. 37, 43-46 (1971) (federal courts generally should dis- 
pose no obstacle to the dismissal of foreigner-foreign state suits. Courts commonly dismiss suits under the doctrine of forum non conveniens. That doctrine has been approved by the Supreme Court, ${ }^{87}$ and frequently has been invoked to mitigate the hardships faced by defendants when defending actions in distant forums. ${ }^{88}$

A motion to dismiss based on the doctrine of forum non conveniens may be granted at the court's discretion. ${ }^{89}$ Several factors are likely to influence the court's decision. A court will dismiss a suit under the rule only if an alternative forum is available. ${ }^{90}$ In addition, the court usually attempts to identify the forum that is most convenient for the parties and that has the greatest interest in the suit. ${ }^{91}$ In some jurisdictions, courts are reluctant to dismiss suits in which at least one of the parties is a citizen or a resident. ${ }^{92}$ The plaintiff's initial choice of forum is usually accorded great weight, and a heavy burden is usually placed on the defendant to show that some other forum would be more convenient. ${ }^{93}$ The doctrine of forum non conveniens as currently formulated would be available to dismiss many foreigner-foreign state suits better adjudicated elsewhere. To serve that end better, however, the doctrine should be modified to account for considerations peculiar to foreigner-foreign state suits.

\section{G. The Sovereign Defendant and Foreign Relations Considerations}

The sovereign status of the defendant may make it inappropriate for a

miss suits seeking to restrain state criminal prosecutions); Gulf Oil Co. v. Gilbert, 330 U.S. 501 (1947) (allowing dismissal based on judicial doctrine of forum non conveniens); Burford v. Sun Oil Co., 319 U.S. 315, 317-18, 332-33 (1943) (federal courts at their discretion may refrain from exercising jurisdiction to avoid interfering with domestic policies of state governments); Railroad Comm'n v. Pullman Co., 312 U.S. 496, 500-01 (1941) (federal court should not decide sensitive constitutional issue when case might be resolved by state court decision of uncertain state law question).

87. Gulf Oil Corp. v. Gilbert, 330 U.S. 501, 507-09 (1947).

88. See R. WEINTRAUB, supra note 22, at 205-06 (courts frequently have used forum non conveniens dismissals to mitigate hardships to defendants resulting from expansion of jurisdiction of American courts).

89. See 15 C. WRight, A. MILler, \& E. COOPER, Federal PRACTICE AND PROCEDURE $§ 3828$ (1976) (forum non conveniens dismissal is within discretion of trial court).

90. See Gulf Oil Corp. v. Gilbert, 330 U.S. 501, 506-07 (1947); Schertenleib v. Traum, 589 F.2d 1156, 1159-60 (2d Cir. 1978).

91. See R. WEINTRAUB, supra note 22, at 205-12 (discussing forum non conveniens generally); notes 76-84 supra (collecting cases specifying factors pertinent to forum non conveniens dismissal).

92. See Medow Indus., Inc. v. Kirsch Co. Inc., 356 F. Supp. 52 (S.D.N.Y. 1973) (applying more restrictive rule of forum non conveniens dismissal in suit by state resident than in suits involving only nonresidents); Archibald v. Cinerama Hotels, 15 Cal. 3d 853, 126 Cal. Rptr. 811, 544 P.2d 947 (1976) (in bank) (same); Comment, Forum Non Conveniens and American Plaintiffs in the Federal Courts, 47 U. CHI. L. REV. 373, 373-74 \& n.9 (1980) (some federal courts invoke forum non conveniens doctrine less readily in suits involving United States citizens than in suits involving only foreigners).

93. See Gulf Oil Corp. v. Gilbert, 330 U.S. 501, 508 (1947) (plaintiffs choice of forum to be accorded great weight); Byrd v. Southern Ry., 203 A.2d 37, 38 (D.C. Ct. App. 1964) (same). 
United States court to exercise its jurisdiction in foreigner-foreign state suits. On the one hand, a foreigner suing a foreign state has a strong claim to the protection of United States courts if it would be difficult to prosecute his or her case in another forum. ${ }^{94}$ On the other hand, the exercise of jurisdiction over a foreign state may adversely affect United States foreign policy interests. The laws of sovereign immunity in other nations often will differ from the rule established by the Foreign Sovereign Immunities Act. ${ }^{95}$ Foreign states may object to suits against them in United States courts that would not be allowed in their own courts. ${ }^{96}$ The United States already is commonly accused of infringing on the sovereignty of other nations by applying American law extraterritorially. ${ }^{97}$ That charge is likely to be raised with special force when United States law is enforced against a foreign state. Finally, even states with no objection in principle to the extraterritorial application of United States law or of United States rules of sovereign immunity may disagree with the application of those rules in particular cases. ${ }^{98}$

The assertion of jurisdiction by a United States court over a foreign state may have repercussions affecting the range of United States relations with that state. Foreign states frequently react to assertions of United States jurisdiction over them by chilling relations with the United States.9

94. See Lacey, Protection of Foreigners' Rights in Mexico, 13 INT'L LAW. 83, 96-97 (1979) (Mexican law giving foreigners right to challenge executive, legislative, and judicial action may be ineffective due to domination of judiciary by executive and other problems in system); p. 1868 supra (suit may be barred by sovereign immunity in alternative jurisdiction but not in United States); $c f$. Lillich, The Diplomatic Protection of Nationals Abroad: An Elementary Principle of International Law Under Attack, 69 AM. J. INT'L L. 359 (1975) (arguing that a state's diplomatic intervention on behalf of its nationals abroad is necessary because their interests are frequently abused by host states).

95. See note 56 supra.

96. See N. LEECH, C. OLIVER, \& J. SWEENEY, supra note 56, at 308 ("socialist" states object to any abrogation of their immunity); Editorial Comment, Sovereign Immunity-The Case of the "Imias," 68 AM. J. INT'L L. 280, 283 (1974) (describing Cuba's assertion to State Department that Cuba was entitled to immunity under international law with respect to its commercial acts, despite "unilateral attempt of the United States to modify that doctrine").

97. See Gordon, Extraterritorial Application of United States Economic Laws: Britain Draws the Line, 14 INT'L LAW. 151 (1980) (describing British objections to extraterritorial application of United States antitrust laws); Development-Antitrust Law: Extraterritoriality, 21 HARV. INT'L L.J. 515, 522 n.45 (1980) (discussing objections by various nations to extraterritorial application of United States antitrust laws). The unusually liberal rules of discovery available in United States courts also provoke foreign state hostility. See Carter, Existing Rules and Procedures, 13 INT'L LAW. 5, 5-7 (1979) (describing foreign state objections to United States court's discovery orders).

98. Cf. Sandler, Vagts, \& Ristau, Sovereign Immunity Decisions of the Department of State, in J. BOYD, DIGEST OF UNITED STATES PRACTICE IN INTERNATIONAL LAW, 1977, at 1072, 1079-80 (1979) (describing State Department characterizations-over opposition of foreign states-of acts as commercial rather than governmental).

99. See, e.g., National Airmotive Corp. v. Iran, 499 F. Supp. 401, 406 (D.D.C. 1980) (executive memorandum pointed out that court proceedings against Iran might restrict President's flexibility in handling hostage crisis); Cardozo, Judicial Deference to State Department Suggestions: Recognition of Prerogative or Abdication to Usurper? 48 CORNELL L.Q. 461, 471 (1963) (Secretary of State's recommendation of immunity for foreign state vessel prompted by concern that retention of jurisdiction would worsen relations with Cuba). 


\section{A Comprehensive Interest-Balancing Test}

Potential inconvenience to the parties, the superior interests of some alternative forum, and the danger of foreign policy complications all militate in favor of foreign court adjudication of some foreigner-foreign state suits that are literally within United States jurisdiction under the terms of the Act. In light of these factors, United States courts should apply a modified rule of forum non conveniens ${ }^{100}$ to distinguish between those cases that American courts should hear and those that they should not.

\section{A. A Rule of Forum Non Conveniens for Foreigner-Foreign State Suits}

In applying the rule of forum non conveniens to foreigner-foreign state suits, a court should first determine whether some alternative forum is capable of according the plaintiff complete relief. ${ }^{101}$ Because the United States has an interest in helping foreigners secure redress for wrongs done to them by foreign states, ${ }^{102}$ a court should be reluctant to dismiss foreigner-foreign state suits if no foreign court can award the plaintiff complete relief. Similarly, a court should disfavor dismissal unless the foreign state consents to submit to jurisdiction elsewhere as a condition for dismissing the action in the United States courts. ${ }^{103}$ In some cases, however, the foreign policy problems involved in adjudicating a foreigner-foreign state suit may outweigh the unfairness of depriving the plaintiff of the only forum in which the action can be brought. In such cases, the suit should be dismissed even if no alternative forum is available.

If another adequate forum is available, the court should then look to the relative convenience and cost to the parties of litigating in that forum, as under present forum non conveniens analysis. ${ }^{104}$ In doing so, the court should consider such factors as the relative availability of witnesses and

100. Appellate courts should be deferential in reviewing applications of this rule by trial courts in view of the many factors involved. See Reyno v. Piper Aircraft Co., 630 F.2d 149, 160 (3d Cir. 1980), cert. granted, $101 \mathrm{~S}$. Ct. 1346 (1981) (trial court's forum non conveniens determination will be upheld unless court has not held defendants to their proper burden or has clearly erred in weighing factors to be considered); Leathers, Dimensions of the Constitutional Obligation to Provide a Forum, $62 \mathrm{KY}$. L.J. 1, 35 (1973) (complexity of forum non conveniens determinations precludes close appellate scrutiny).

101. See p. 1873 supra (traditional forum non conveniens doctrine precludes dismissal unless alternative forum is available).

102. Cr. pp. 1870-71 supra (United States interest in promoting human rights may be furthered by permitting foreigner-foreign state suits).

103. Courts typically require a defendant to waive valid objections to suit in another forum as a condition for dismissing the suit. See, e.g., Fitzgerald v. Texaco, Inc., 521 F.2d 448, 449, 453 (2d Cir. 1975), cert. denied, 423 U.S. 1052 (1976) (forum non conveniens dismissal conditioned on submission by defendants to jurisdiction of foreign court); Pertichino v. Meridional Pesca Degiosa, Inc., $444 \mathrm{~F}$. Supp. 190, 191 (S.D.N.Y. 1978) (same).

104. See notes 76-81 supra (collecting cases specifying factors of convenience to the parties pertinent to forum non conveniens dismissal). 
evidence. The court also should determine whether the plaintiff chose a United States forum in order to harass the defendant by forcing it to litigate in a distant and unfamiliar jurisdiction. ${ }^{105}$

In addition, the court should ascertain whether adjudication of the suit is likely to strain United States relations with the defendant foreign state. ${ }^{106}$ In making that assessment, the court should focus on the size of the claim, the political or non-political nature of the suit, ${ }^{107}$ the prior expectations of the foreign state, ${ }^{108}$ and the existing relationship of the United States with the foreign state. ${ }^{109}$

The court should also consider the law that would govern the case in determining whether or not to dismiss. First, the risk of error and the inconvenience involved in finding and applying foreign law weigh in favor of dismissing a foreigner-foreign state suit that would be governed by foreign law under United States choice of law rules. ${ }^{110}$ Second, the choice of

105. See Ionescu v. E.F. Hutton \& Co. (France) S.A., 465 F. Supp. 139, 147 (S.D.N.Y. 1979) (dismissing suit because plaintiff's choice of forum motivated primarily by intent to harass defendant).

106. See p. 1874 supra (discussing foreign policy repercussions of assertion of jurisdiction over foreign states). United States courts have developed various rules of judicial construction and abstention in response to the perception that their handling of suits involving foreign states or acts occurring in foreign states could disrupt United States foreign relations. For example, courts have applied United States antitrust laws differently depending on how enforcement of those laws would affect foreign relations. See Mannington Mills, Inc. v. Congoleum Corp., 595 F.2d 1287, 1296 (3d Cir. 1979) (foreign relations considerations may dictate judicial abstention in antitrust cases); Timberlane Lumber Co. v. Bank of America, N.T. \& S.A., 549 F.2d 597, 611-12 (9th Cir. 1976) (extraterritorial reach of antitrust laws depends, in part, on considerations of comity with forcign states).

With certain exceptions, the act of state doctrine forbids judicial inquiry into the validity of an act of a foreign government done within its own territory. See Comment, The Act of State Doctrine: $A$ History of Judicial Limitations and Exceptions, 18 HARV. INT'L L.J. 677, 677, 680 (1977). This doctrine is supported by the quasi-constitutional notion that courts should not embarrass executive branch conduct of foreign relations by determining the legality of acts of foreign states. See Banco Nacional de Cuba v. Sabbatino, 376 U.S. 398, 423 (1964) (act of state doctrine has "constitutional underpinnings"); Maier, supra note 10, at 49 (1976) (discussing constitutional basis of sovereign immunity defense).

Even retention of the doctrine of sovereign immunity in federal common law until the passage of the Act has been explained as a judicial attempt to avoid interfering with the executive's conduct of foreign relations. See Victory Transp. Inc. v. Comisaria Gen., 336 F.2d 354, 357 (2d Cir. 1964), cert. denied, 381 U.S. 934 (1965).

107. For example, a suit based on a politically-inspired libel, see Yessenin-Volpin v. Novosti Press Agency, 443 F. Supp. 849 (S.D.N.Y. 1978) (suit by Soviet expatriate against Sovict press agency), should be more readily dismissed than other claims. But such suits should not automatically be barred. Some political acts may be so odious, see, e.g., Filartiga v. Pena-Irala, 630 F.2d 876 (2d Cir. 1980) (politically motivated torture); Letelier v. Republic of Chile, 488 F. Supp. 665 (D.D.C. 1980) (politically motivated murder), that considerations of justice outweigh purely political considerations.

108. A prior contractual waiver of immunity, for example, should weigh against dismissal under the proposed rule.

109. Cf. American Int'l Group, Inc. v. Iran, No. 80-1779 (D.C. Cir. Sept. 26, 1980) (ordering stay in proceedings against Iran to avoid disrupting hostage negotiations); National Airmotive Corp. $v$. Iran, 499 F. Supp. 401, 406-07 (D.D.C. 1980) (same).

110. Traditional forum non conveniens analysis recognizes this aspect of the choice of law issue. See p. 1872 supra. 
law may help determine which forum has a superior interest in having the dispute litigated in its courts. ${ }^{111}$ If the United States court and the alternative forum would apply the same law, or if their different laws serve the same objectives, resolution of the dispute by either forum will serve the substantive policies of both states. But if the foreign court would apply a rule that conflicts with the policy underlying the United States rule, the United States court should retain the case in order to further the United States policy.

Finally, the court should ascertain whether there is any danger that the plaintiff's claim will be handled unfairly in the alternative forum. The United States court should not presume that foreign courts will be unfair or tainted by inadequate procedures, ${ }^{112}$ but these dangers should receive appropriate consideration in the court's analysis. ${ }^{113}$

\section{B. The Rule's Application}

The proposed rule should apply only to suits by plaintiffs who are not United States residents or lawfully admitted visitors. ${ }^{14}$ Congress' goal of

111. Only a few courts have considered how alternative forums would decide the choice of law issue before deciding whether or not to dismiss a suit. See, e.g., Dahl v. United Technologies Corp., 632 F.2d 1027, 1032-33 (3d Cir. 1980) (dismissing for forum non conveniens in part because Norway's interest in reducing accidents in Norwegian territory is greater than United States interest in maintaining integrity of aircraft certification process); Reyno v. Piper Aircraft Co., 630 F.2d 149, 163-71 (3d. Cir 1980), cert. granted, 101 S. Ct. 1346 (1981) (denying motion to dismiss in part because United States courts would apply laws of Ohio and Pennsylvania, the jurisdictions most interested in the dispute, while Scottish courts would apply law of Scotland, the jurisdiction where injury occurred); Fitzgerald v. Texaco, Inc., 521 F.2d 448, 453 (2d Cir. 1975), cert. denied, 423 U.S. 1052 (1976) (dismissing suit for a collision on high seas in part because "England clearly has the more direct interest in promulgating and enforcing rules for the safe passage of traffic in the English Channel").

112. See Comment, supra note 92 , at 387 (presumption against competence and fairness of foreign courts for purposes of forum non conveniens determination unjustified, and inconsistent with presumption of adequacy for purposes of recognizing foreign judgments).

113. See, e.g., Mobil Tankers Co. v. Mene Grande Oil Co., 363 F.2d 611, 614-15 (3d Cir.), cert. denied, 385 U.S. 945 (1966) (reversing forum non conveniens dismissal because of inadequate foreign procedures); Phoenix Can. Oil Co. v. Texaco, Inc., 78 F.R.D. 445, 455-56 (D. Del. 1978) (refusing forum non conveniens dismissal in part because of military junta's interference with judiciary of alternative jurisdiction); Flota Maritima Browning, S.A. v. The Ciudad, 181 F. Supp. 301, 311 (D. Md. 1960) (refusing dismissal because corporation almost wholly owned by United States citizen unlikely to receive justice in courts of Cuba); Oppenheimer v. Louis Rosenthal \& Co., [1937] 1 All E.R. 23 (C.A. 1936) (declining to dismiss suit by German Jew in favor of courts of Nazi Germany).

114. In some cases, a foreign plaintiff should be considered a United States citizen for the purposes of the rule. A foreign company wholly owned by United States citizens, for example, should be treated as a citizen. Cr. Ghemical Carriers, Inc. v. L. Smit \& Co.'s Internationale Sleepdienst, 154 F. Supp. 886, 889 (S.D.N.Y. 1957) (refusing dismissal in part because plaintiff Liberian corporation had its principal place of business in United States). But see United Continental Tuna Corp. v. United States, 550 F.2d 569, 572-74 (9th Cir. 1977) (applying rule allowing suits in admiralty by foreigners against United States only on the basis of reciprocity even though $99 \%$ of plaintiff Philippine corporation was owned by United States citizens).

On the other hand, a plaintiff who is a United States citizen or resident should be treated as a foreigner for purposes of the rule when suing as the subrogee, assignee, or representative of a foreigner. See, e.g., United States Merchants' \& Shippers' Ins. Co. v. A/S Den Norske Afrika Og Aus- 
protecting American citizens and preserving their due process rights would be defeated if the rule were applied to suits by United States citizens. ${ }^{115}$ And although discrimination against aliens lawfully within the United States is permitted in some cases, ${ }^{116}$ applying the proposed rule to resident aliens would probably violate their constitutional rights. ${ }^{117} \mathrm{By}$ contrast, foreigners not within the United States are generally outside the protection of the Constitution. ${ }^{18}$ Thus, it would not be unconstitutional to apply the rule to any individual who is not a citizen, a resident, or a lawful visitor to the United States.

Although the proposed rule would discriminate against foreigners as a class, it would not violate customary international law. ${ }^{119}$ Customary international law does not require that foreigners be given access to a state's courts on the same basis as citizens. Many states favor their own citizens in allowing access to their courts. ${ }^{120}$ For example, foreigners generally have standing to sue the United States or its agencies only if they own property in the United States that is the subject matter of the suit, or if a statute explicitly grants them standing. ${ }^{121}$

tralie Line, 65 F.2d 392, 394 (subrogee); Del Monte Corp. v. Everett S.S. Corp., 402 F. Supp. 237, 243 (N.D. Cal. 1973) (assignee).

115. See H.R. REP. No. 1487, supra note 2, at 6605 (one goal of Act is to protect rights of United States citizens in their relations with foreign states); id. at 6606 (elimination of State Department's role was intended to preserve due process). Some suits by United States citizens against foreign states could still be dismissed on traditional forum non conveniens grounds. Cf. Comment, supra note 92, at 373 n.8 (discussing dismissal of suits by United States citizens against foreign defendants on forum non conveniens grounds).

116. E.g., Mathews v. Diaz, 426 U.S. 67 (1976) (upholding federal legislation requiring both permanent residence status and five years residence in United States for alien eligibility for social security benefits).

117. See Gordon, The Alien and the Constitution, 9 CAL. W.L. REV. 1, 14 (1972) (aliens resident in United States have a right of access to United States federal courts); cf. Hampton v. Mow Sun Wong, 426 U.S. 88 (1976) (discrimination against resident aliens permissible only if justified by overriding national interests).

118. See Johnson v. Eisentrager, 339 U.S. 763, 771 (1950) ("[I]n extending constitutional protections beyond the citizenry, the Court has been at pains to point out that it was the alien's presence within its territorial jurisdiction that gave the Judiciary power to act."); L. HENKIN, FOREIGN AFFAIRS AND THE CONSTITUTION 267 (1972) (alien nonresidents abroad not entitled to protection of Constitution). But see United States v. Cortes, 588 F.2d 106 (5th Cir. 1979) (aliens arrested in international waters by Coast Guard for drug smuggling entitled to raise Fourth Amendment defense because Coast Guard actions constituted assertion of United States governmental power abroad).

119. Customary international law relates to "customs and usages" of nations that are considered binding on all states because of their general acceptance. The Paquete Habana, 175 U.S. 677, 700 -. (1900).

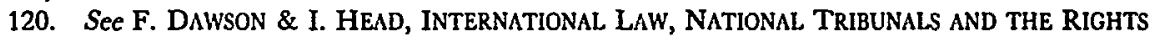
OF ALIENS 129-131 (1971) (European states often grant an alien only those rights that the alien's home country grants to nationals of the forum state); id. at 135 (courts of many nations, which commonly require alien and nonresident plaintiffs to deposit security for costs, "easily could block a nonresident's access by granting defendant's motion for an excessively high deposit"); id. at 150 (right of aliens to sue in forma pauperis generally conditioned on residence in state).

121. See, e.g., Kukatush Mining Corp. v. SEC, 309 F.2d 647 (D.C. Cir. 1962) (denying alien standing to sue United States); Berlin Democratic Club v. Rumsfeld, 410 F. Supp. 144 (D.D.C. 1976) (same); 46 U.S.C. $\$ 785$ (1976) (conditioning right of foreign nationals to sue United States in 


\section{Foreigner-Foreign State Suits}

A number of foreign states have treaties with the United States that guarantee to their citizens the right to invoke the protection of United States courts on the same basis as United States citizens. ${ }^{122}$ The case law interpreting these treaties is sparse. ${ }^{123}$ Nonetheless, it seems clear that these treaties will seldom prevent United States courts from applying the proposed rule of forum non conveniens in foreigner-foreign state suits. ${ }^{124}$

\section{Conclusion}

The recent expansion of United States jurisdiction over foreignerforeign state suits generally will serve United States interests. Exercising this jurisdiction, however, will sometimes cause inconvenience to the parties, conflict with the superior interest of some other forum in resolving the dispute, or complicate United States relations with other nations. Thus, United States courts should sensitively apply the proposed rule of forum non conveniens to avoid deciding those cases that should be resolved in the courts of other nations.

admiralty on availability in foreign nationals' countries of reciprocal right for United States nationals).

122. See, e.g., Treaty of Friendship, Commerce and Navigation, Aug. 23, 1951, United States-Isracl, art. V, para. 1, 5 U.S.T. 550, T.I.A.S. No. 2948 ("Nationals and companies of either Party shall be accorded national treatment and most-favored nation treatment with respect to access to the courts of justice and to administrative tribunals and agencies within the territories of the other Party, in all degrees of jurisdiction, both in pursuit and in defense of their rights."); Treaty of Friendship, Commerce and Navigation, Nov. 28, 1956, United States-Korea, art. V, para. 1, 8 U.S.T. 2217, T.I.A.S. No. 3947 (same).

123. See, e.g., Buechold v. Ortiz, 401 F.2d 371, 372 (9th Cir. 1968) (treaty does not require federal court to hear claim that United States citizen would not be able to maintain); Damaskinos v. Societa Navigacion Interamericana, S.A., 255 F. Supp. 919, 923 (S.D.N.Y. 1966) (when United States plaintiff would have no remedy, equal access treaty provision does not require opening federal court to forcign plaintiff).

124. First, it is unclear whether these treaties even affect the power of United States courts to apply the rules of forum non conveniens. While this question has been discussed in dictum, compare Alcoa S.S. Co. v. M/V Nordic Regent, No. 78-7054, slip op. at 5957 (2d Cir. Feb. 25, 1980) (en banc) (treaties forbid discriminatory application of forum non conveniens doctrine) with id., slip op. at 5984-85 (van Graafeiland, J., dissenting) (treaties do not apply to decision of forum non conveniens motions), no court has ruled on the issue. Second, most of the treaties contain a provision that permits a state to take measures "necessary to fulfill the obligations of a Party for the maintenance or restoration of international peace and security, or necessary to protect its essential security interests." Treaty of Friendship, Commerce, and Navigation, United States-Israel, supra note 122, at art. XXI, para. 1(d). Thus, the proposed rule could be applied without violating those treaties whenever dismissal of a foreigner-foreign state suit is necessary to protect "essential security interests." 